\title{
6. BATHYMETRY AND STRUCTURE OF THE BAUER DEEP AROUND DSDP SITE 319
}

\author{
Robert S. Yeats, Department of Geology, Ohio University, Athens, Ohio \\ and \\ G. Ross Heath, ${ }^{1}$ Graduate School of Oceanography, University of Rhode Island, Kingston, Rhode Island
}

\begin{abstract}
Site 319 was drilled in the southern Bauer Deep in a basin about 6 $\mathrm{km}$ across containing about 100 meters of sediment as old as 14.5 m.y. Northwest-trending ridges and fault scarps in the sea floor and the northwest grain of the basement topography beneath the basin are consistent with formation at the northeast-southwest spreading Galapagos Rise Crest.
\end{abstract}

\section{INTRODUCTION}

The site survey of Site 319, when combined with earlier surveys by the R/V Yaquina (YALOC-73, Leg 3) and by the R/V Kana Keoki (1973, Leg 3), defines the structural grain of this portion of the Bauer Deep and its relation to sediment accumulation and to formation of the Galapagos Rise.

The Bauer Deep lies between the northeast-trending East Pacific Rise and the northwest-trending Galapagos Rise (Figure 1). The eastern boundary of the East Pacific Rise at the latitude of the site is a zone of rugged topography separating shallower terrain nearly free of sediment from deeper terrain with sediment mantling ridges and basins. The most recent bathymetric map of the southeastern Pacific (Mammerickx et al., 1975) shows the Bauer Deep with a northerly to northeasterly structural grain. Yet a bathymetric survey of the southern Bauer Deep at 20-min intervals of latitude by the R/V Yaquina as part of YALOC-73, Leg 3, shows relatively poor topographic correlation between tracks (Figure 2), raising the possibility that the structural grain may not be northerly.

\section{DATA}

The sea floor at Site 319 has a basin and range topography with relatively steep ridges and low-relief but broadly sloping basins with a strong northwest grain (Figure 3). The relief of the sea floor is about 300 meters in the vicinity of the site, but is perhaps twice this amount in adjacent areas (Figure 2). The basin in which Site 319 is located contains a thin sedimentary sequence overlying a basement surface having relief of at least 50 meters $(0.07 \mathrm{sec})$ that appears to be primarily of volcanic origin. The irregularity of the basement surface is confirmed by the 13-meter difference in basement depth at Holes 319 and 319A, drilled by Glomar Challenger using the same beacon. The grain of the basement topography is also northwest, as can be seen by comparing the sedi-

\footnotetext{
${ }^{1}$ Formerly School of Oceanography, Oregon State University, Corvallis, Oregon.
}

ment isopachs (Figure 4) with the bathymetry (Figure 3) southeast of Site 319.

Airgun and $3.5-\mathrm{kHz}$ records show that the sedimentary sequence consists of a well-stratified unit overlying a nonstratified unit that is acoustically nearly transparent (Figures 5, 6, 7). Drilling results at Site 319 show that the well-stratified upper unit consists of slowly accumulating clay and ooze, relatively rich in metalliferous components, of late Miocene to Quaternary age, and that the featureless lower unit is principally rapidly deposited nannofossil ooze, of middle Miocene age. The oldest sediments are about 14-14.5 m.y. in age. Most of the relief of the top of the basement in the basins is filled in by the nonstratified nannofossil ooze, but the upper stratified sediments overlie higher parts of the basement directly at many localities, including the elongate ridge northeast of the site (Figure 6). The stratified unit decreases in thickness slightly northeastward from Site 319 toward the ridge; individual thin beds within this unit also decrease in thickness (Figures 6, 7). The stratified beds on top of the ridge are somewhat thinner than those in the basin (Figure 4). Stratification is parallel to the sea floor in the basin; both have slopes of less than $0.2^{\circ}$.

The margins of the basins are interpreted as fault surfaces rather than volcanic slopes because the slopes are strongly linear. The parallelism of the marginal faults with the grain of the basement topography within the basin suggests a common origin. Several lines of evidence suggest that the faults formed prior to sedimentation: (1) the thickness of stratified beds is reduced atop the ridges; (2) the thickness of the stratified unit and of individual members within this unit decreases from the center of the basin toward its margins; (3) the transparent unit is absent from topographically high areas, suggesting that the high-standing blocks were present during the time carbonate ooze was deposited, and the sediments were carried down to the basins by slow moving bottom currents; and (4) sediments generated by bottom currents that would be expected in cores from Site 319 if basement blocks were uplifted after they were mantled by sediment are not found. Cores taken on Leg 3 of YALOC-73 recovered foraminiferal clay at 3971 meters at $13^{\circ} \mathrm{S}, 100.5^{\circ} \mathrm{W}$, indicating that the calcite compensation depth (CCD) for the youngest sediments 


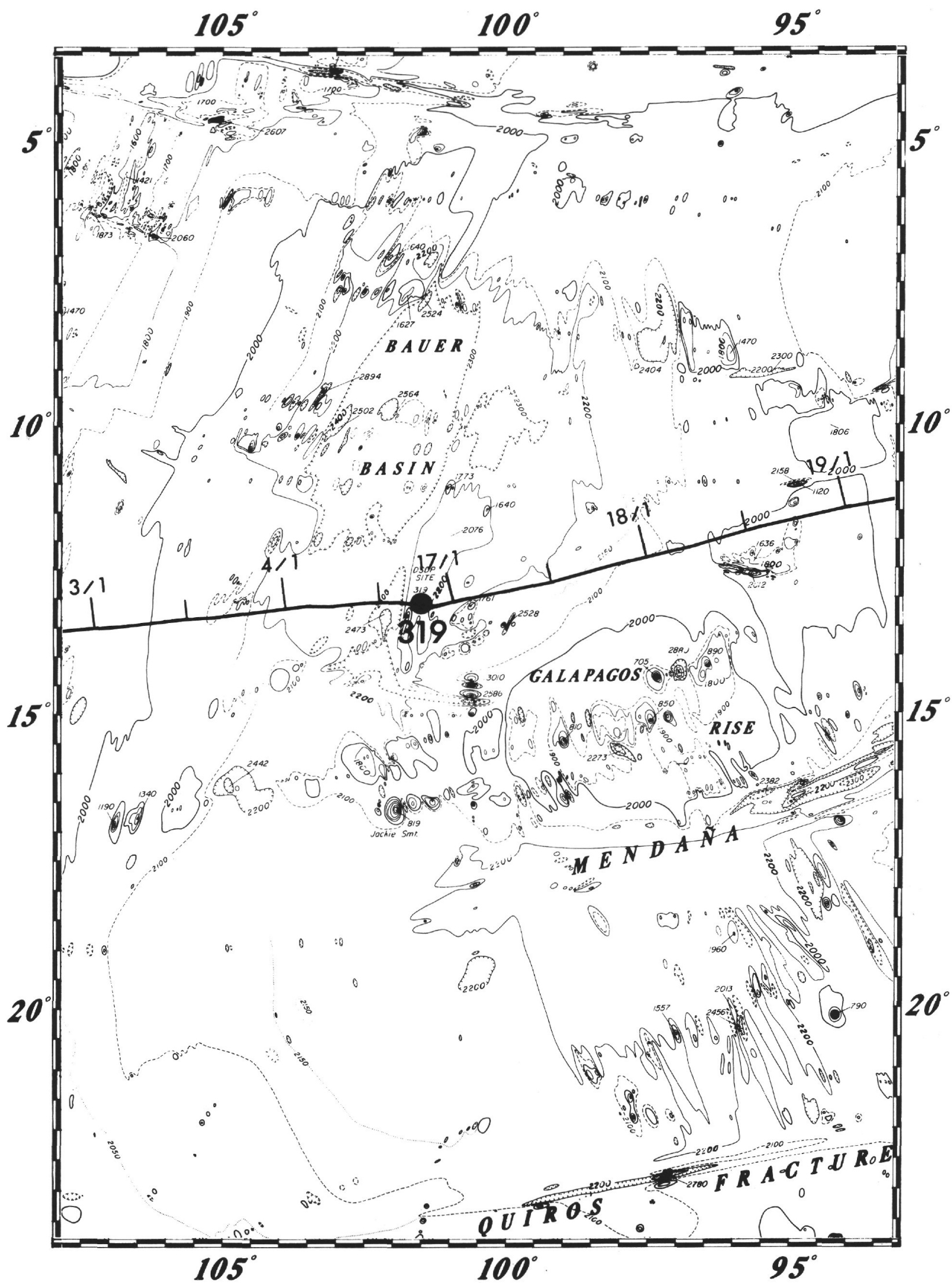

Figure 1. Bathymetric map of the northwestern Nazca plate, covering the Bauer Deep, Galapagos Rise, and part of the East Pacific Rise (from Mammerickx et al., 1975). Depths in fathoms. 


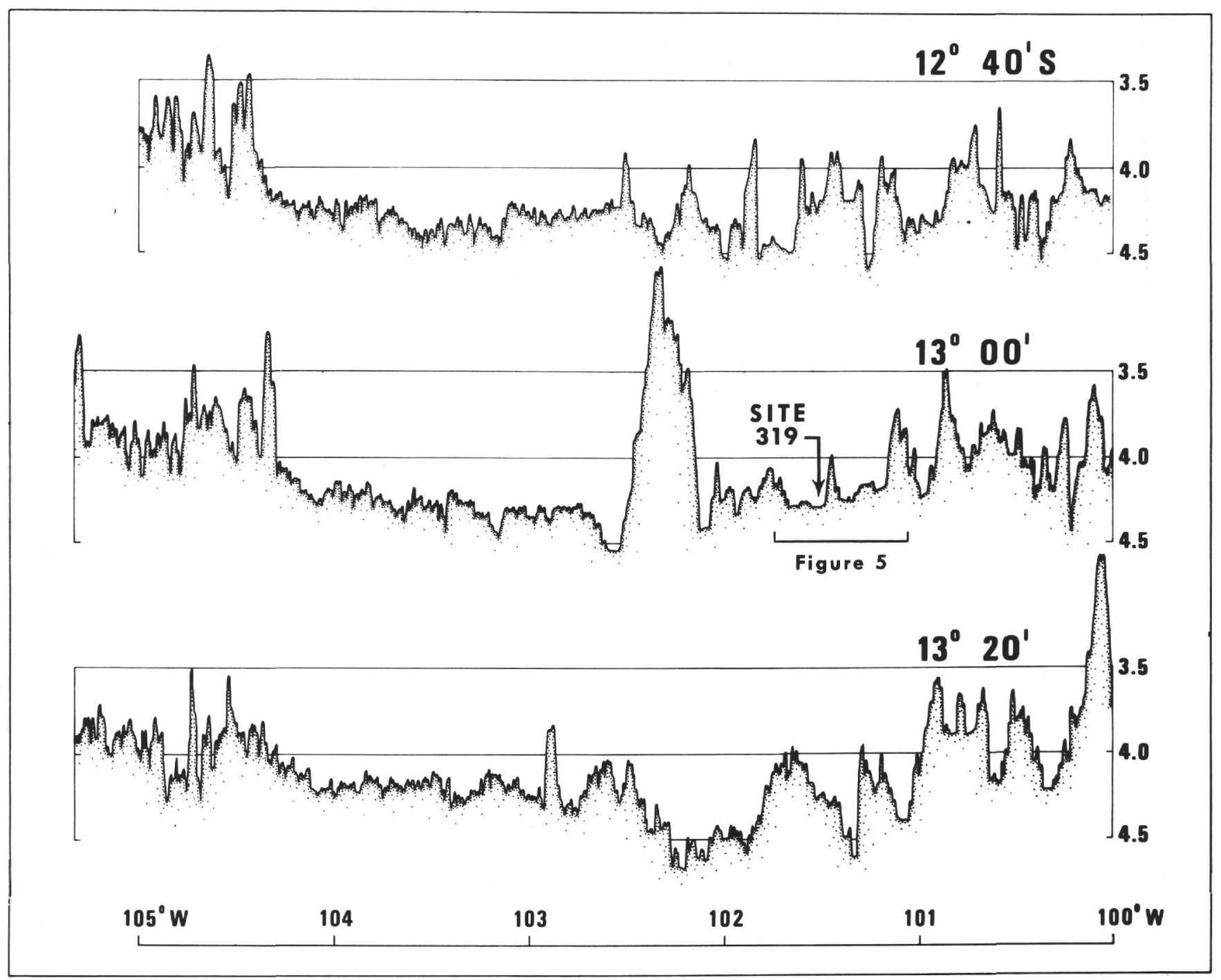

Figure 2. East-west bathymetric profiles across the southern Bauer Deep (YALOC-73, Leg 3). Vertical scale in kilometers, corrected using Matthews tables. East edge of East Pacific Rise is between $104^{\circ}$ and $105^{\circ} \mathrm{W}$ in each profile; topography east of $103^{\circ}$ cannot be correlated between profiles.

lies below this depth and above 4280 meters, the water depth at Site 319. Thus, the youngest stratified beds were deposited on the present basement topography. The stratified sediments are not visibly disturbed at basin margins, appearing to be draped over the basement rather than faulted against it.

\section{DISCUSSION}

The geologic history of this portion of the Bauer Deep appears to be: (1) formation of a northwest-trending volcanic topography, (2) block faulting along the same northwest trend, (3) middle Miocene deposition of nannofossil ooze above the contemporaneous CCD in basins as they exist today, and (4) deposition of late Miocene to Quaternary metalliferous clays below the CCD (presumably due to subsidence of the sea floor). The oldest sediment overlying basalt (14-14.5 m.y.) is markedly younger than the 20-25 m.y. age of the crust predicted from bathymetry (Sclater et al., 1971; Anderson and Sclater, 1972: Mammerickx et al., 1975). The sedimentation rate of metalliferous components was high in the lower part of the section at Site 319 , indicating proximity to an active spreading center and suggesting that the Sclater et al. (1971) relationship is not strictly applicable in the Bauer Deep.

The northwest fault trends and grain of the basement topography suggest that the sea floor formed at a spreading center trending at about $315^{\circ}$. The basal sediments at Site 319 are too old to have been deposited on crust generated by the East Pacific Rise spreading at the rate of $8 \mathrm{~cm} / \mathrm{yr}$ (Mammerickx et al., 1975). The Galapagos Rise is the probable source, but the orientation of the rise crest suggested by Herron (1972) and Mammerickx et al. (1975) is more northerly than the orientation suggested here. The parallelism of subbasin topography and basin margin faults supports our interpretation, but the restricted area covered by the survey leaves the trend open to some question.

The principal justification for the more northerly orientation of the Galapagos Rise cited by Herron 


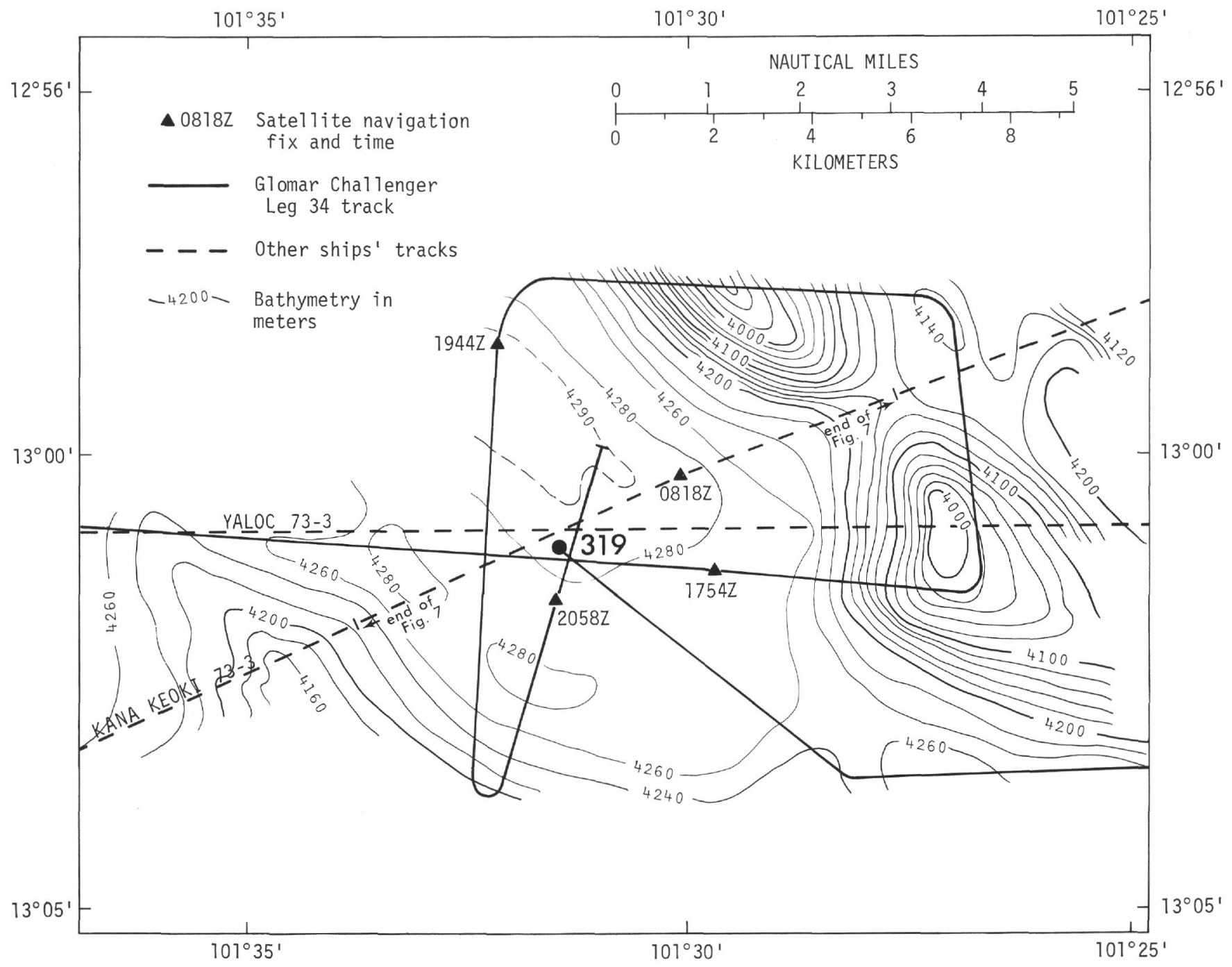

Figure 3. Bathymetry around Site 319, based on tracks of YALOC-73, Leg 3, Kana Keoki-73, Leg 3, and Glomar Challenger

Leg 34. Depths are in meters, corrected using Matthews tables, Area 41.

(1972) and Mammerickx et al. (1975) is the eastnortheast orientation of its major fracture zones (Mendaña, Quiros, Sala-y-Gomez, and Easter fracture zones; Mammerickx et al. (1975). The orientation of the rise crest itself is not clear from existing topographic maps, although a survey at $10^{\circ} 20^{\prime} \mathrm{S}, 93^{\circ} 20^{\prime} \mathrm{W}$ by $\mathrm{R} / \mathrm{V}$ Yaquina (YALOC-71, Leg 7) shows a well-developed linear topography trending at $335^{\circ}$. Site 319 appears to lie on a strip of crust north of an unnamed fracture zone on trend with the Sarmiento Ridge off northwestern Peru; in this strip, the Galapagos Rise is poorly defined and some $700-800 \mathrm{~km}$ east of the site (Mammerickx et al., 1975).

The northeast trend of the aseismic Nazca Ridge, and, to a lesser extent, of the eastern terminus of the Mendaña Fracture Zone and the Sarmiento and Grijalva ridges deviates markedly from the more easterly trends near the crest of the Galapagos Rise. If the Mendaña Fracture Zone was formed by spreading from a single pole of rotation, its curvature implies a high rotational latitude with respect to this pole. Alternatively, the older, eastern portion of the Mendaña Fracture Zone may have been formed during an earlier period of spreading that trended more northeasterly than the spreading which formed the western part of the Mendaña Fracture Zone and the fracture zones farther south. The abrupt eastern termination of the Easter and Sala-y-Gomez Fracture Zones at the southwest end of the Nazca Ridge supports the concept of a change in spreading direction, and raises the possibility that the Nazca Ridge may be a fracture zone. Magnetic anomalies identified by Mammerickx et al. (1975) indicate that this change in direction occurred earlier than the formation of anomaly 7, about 25-30 m.y. ago. The structural grain in the Bauer Deep near Site 319 is consistent with formation prior to such a change in spreading direction. If the site is older than 25 m.y., it appears that (1) the Sclater et al. (1971) age-depth relationship is approximately correct for the area around Site 319, and (2) burial of older deposits by basalt flows took place up to $10 \mathrm{~m}$.y. after formation of the crust. However, the fact that the Site 319 basalts are 


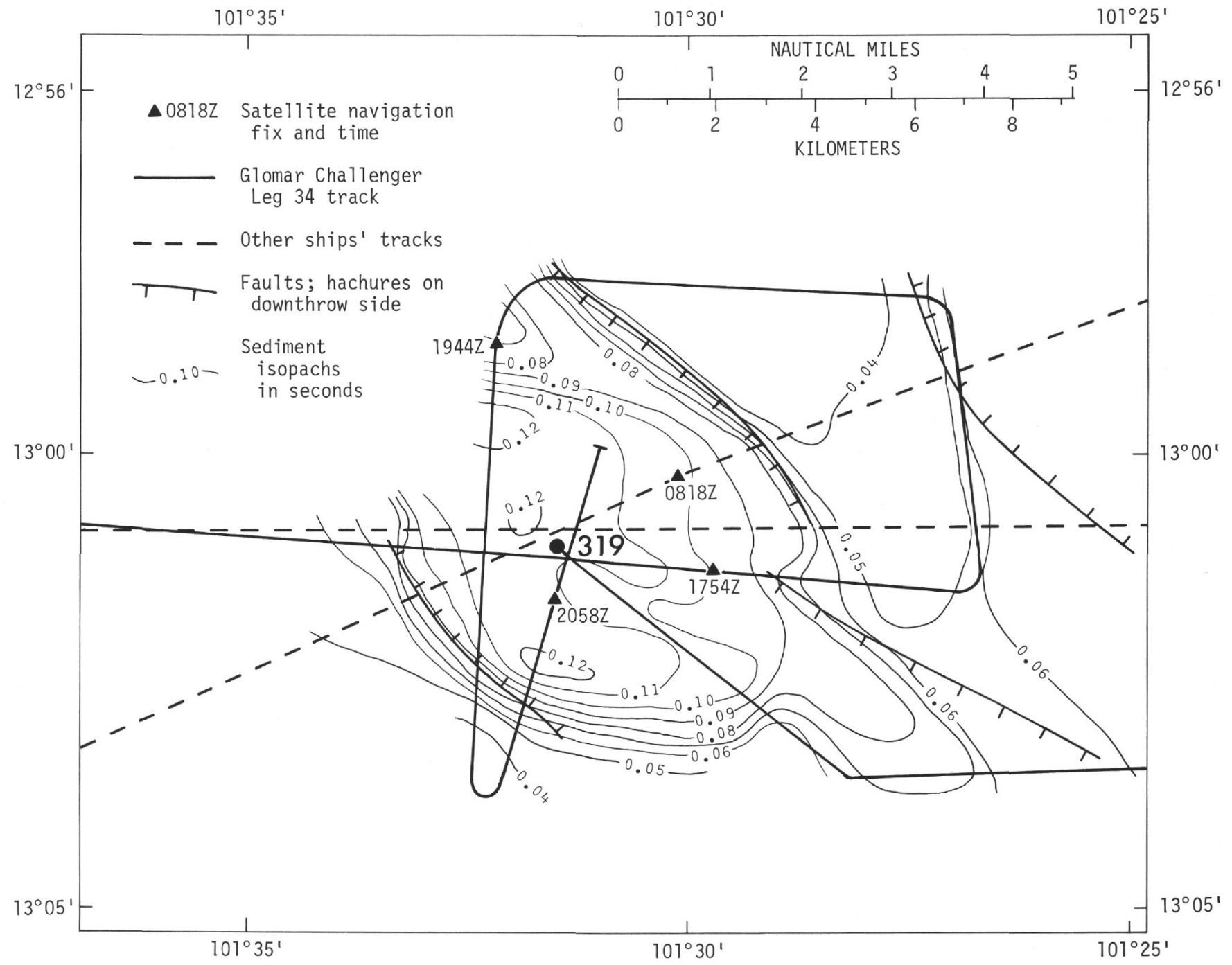

Figure 4. Sediment thickness around Site 319 (isopachs are in two-way travel time sec). Fault positions based on isopachs and bathymetry. Sediment thickness is 112 meters in Hole 319 and 98 meters in Hole $319 \mathrm{~A}$.

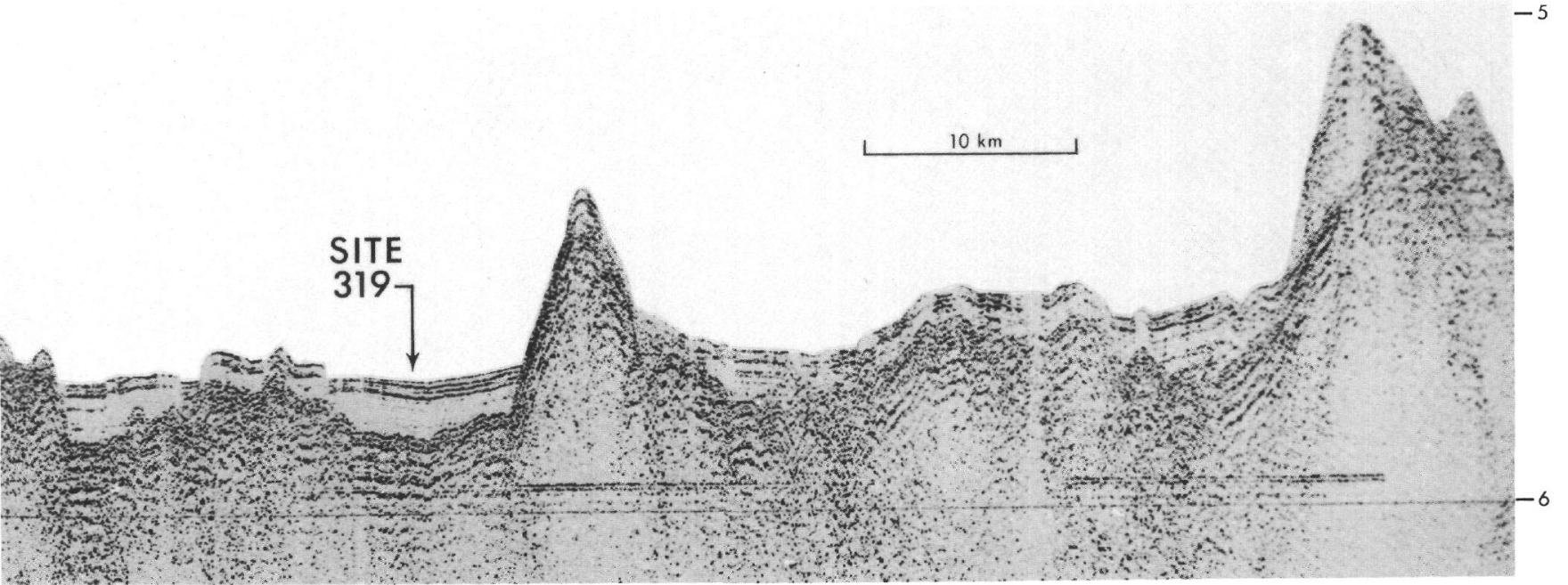

Figure 5. Airgun profile across Site 319 made during YALOC-73, Leg 3. West is to left. At the site, note the well-stratified unit of nearly constant thickness overlying an acoustically transparent unit which, in turn, overlies volcanic basement of moderate relief. The transparent unit is also seen in the basin to the west and, discontinuously, at $15 \mathrm{~km}$ and $37 \mathrm{~km}$ east of Site 319. 


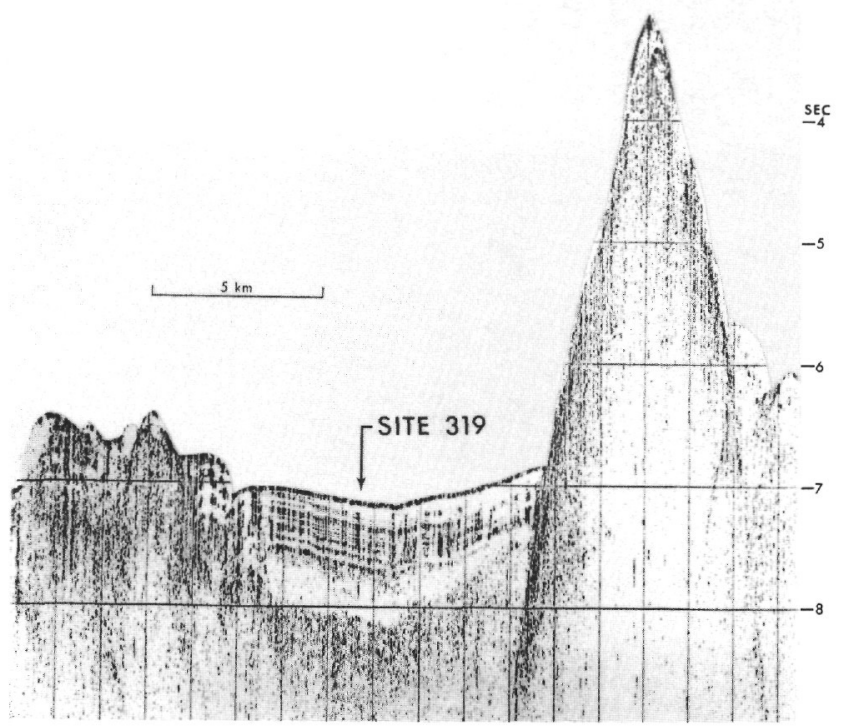

Figure 6. 3.5- $\mathrm{kHz}$ reflection profile across Site 319 , made during YALOC-73, Leg 3, showing basement relief, transparent sedimentary unit, and well-stratified unit. Note eastward thinning of the well-stratified unit and of thin layers within this unit against the steep ridge, and the presence of a thin section of stratified sediments on ridge top and flanks.

NE

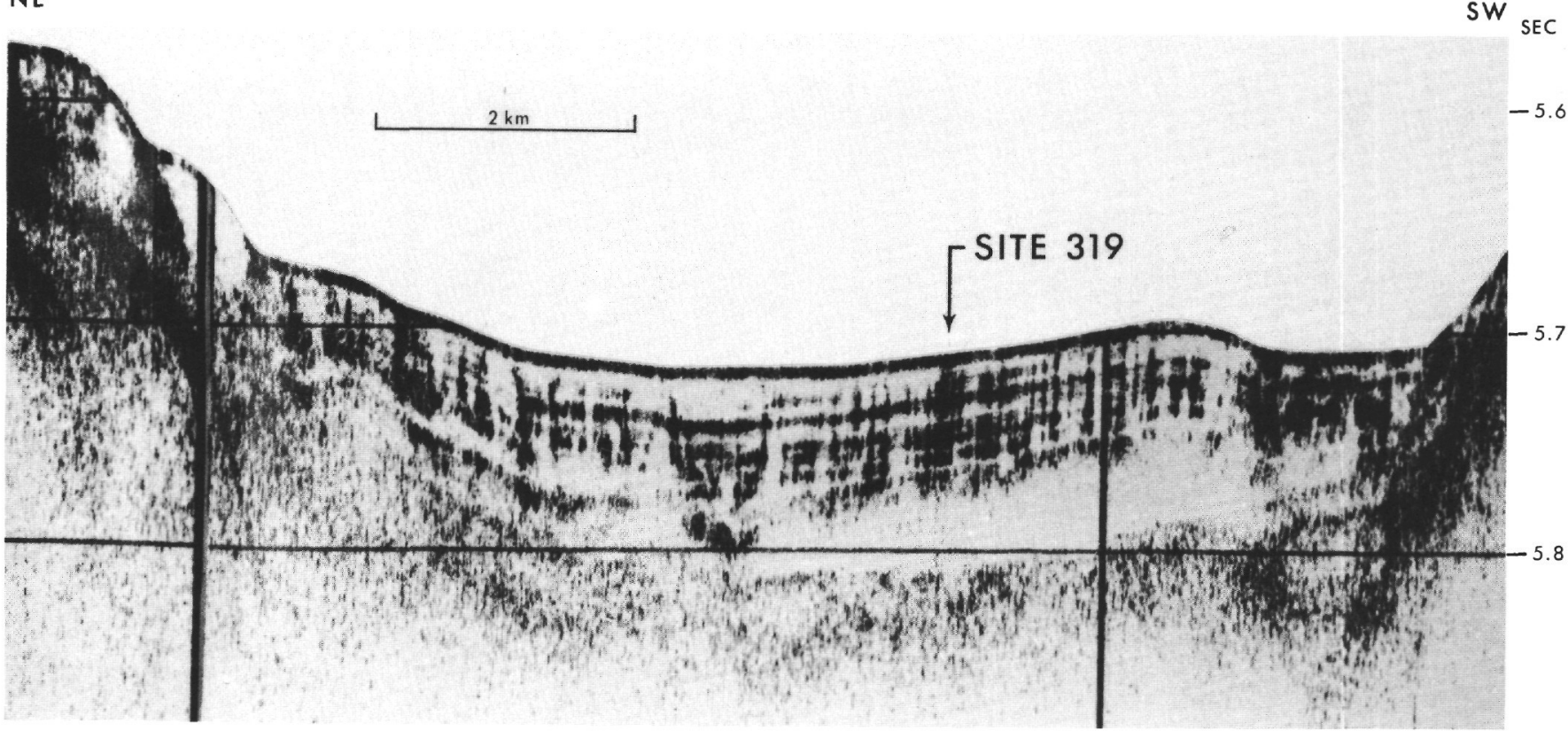

Figure 7. 3.5-kHz reflection profile across Site 319 made during Kana Keoki-73, Leg 3. Northeast is to left. Well-stratified unit thins against the northeast ridge and, within the basin, to the southwest of the site. Abrupt thinning of the basin sediments at the base of the slopes at the ends of the record shown is attributed to nondeposition on steep, early-formed fault scarps. typical rise-crest tholeiites (S.R. Hart, this volume) argues against an episode of late, off-ridge volcanism and suggests that the 25 -m.y. age is improbable.

Clearly, a detailed bathymetric survey of a larger area is required to resolve unequivocally the topographic grain and structural setting of the Bauer Deep.

\section{ACKNOWLEDGMENTS}

The Yaquina and Kana Keoki records were provided by Oregon State University and Hawaii Institute of Geophysics, respectively. Both surveys form part of the Nazca Plate Project funded by the International Decade of Ocean Exploration Office of the National Science Foundation (Grant No. GX28675). The paper was reviewed by William Benson and Jacqueline Mammerickx. A preprint of the paper and bathymetric map by Mammerickx et al. (1975) was most helpful in preparing this chapter.

\section{REFERENCES}

Anderson, R.N. and Sclater, J.G., 1972. Topography and evolution of the East Pacific Rise between $5^{\circ} \mathrm{S}$ and $20^{\circ} \mathrm{S}$ : Earth Planet. Sci. Lett., v. 14, p. 433-441.

Herron, E.M. 1972. Sea floor spreading and the Cenozoic history of the east-central Pacific: Geol. Soc. Am. Bull., v. 83 , p. 1671-1692.

Mammerickx, J., Anderson, R.N., Menard, H.W., and Smith, S.M., 1975. Morphology and tectonic evolution of the east central Pacific: Geol. Soc. Am. Bull., v. 86, p. 111-118.

Sclater, J.G., Anderson, R.N., and Bell, M.L., 1971. Elevation of ridges and evolution of the central eastern Pacific: J. Geophys. Res., v. 76, p. 7888-7915. 